\title{
FRACTURES IN STILL'S DISEASE
}

BY

\author{
B. W. D. BADLEY AND BARBARA M. ANSELL \\ Rheumatism Research Unit (M.R.C.), Canadian Red Cross Memorial Hospital, Taplow, Bucks
}

The introduction of corticosteroid therapy in rheumatoid arthritis was followed by reports of fractures, particularly vertebral, occurring in patients receiving such treatment. This paper reviews the incidence and types of fractures occurring in patients with juvenile rheumatoid arthritis who have attended this hospital during the past 12 years, a small number of whom have received steroid therapy.

\section{Material and Methods}

The material consists of 216 cases of juvenile rheumatoid arthritis seen since 1947 and followed to June, 1959. For this diagnosis to be made, a polyarthritis involving four or more joints, commencing before the age of 16 years, and persisting for more than 3 months, without evidence of other disease such as systemic lupus erythematosus, ulcerative colitis or psoriasis, either initially or at follow-up, was required. 26 cases with involvement of less than four joints were also included when a synovial biopsy was compatible with the diagnosis, as were 48 patients with peripheral polyarthritis who later showed radiological sacro-iliac changes without spinal involvement.

A careful study of any earlier hospital records and the original $x$ rays is made at the initial assessment of all cases referred here. In-patients are regularly reviewed, and, except under special circumstances, out-patients are seen at least annually, when a full history is taken of events occurring since the previous visit. Any relevant episode reported is investigated by contacting the doctor or hospital where treatment was given.

The basic management of all these cases has consisted of physiotherapy with emphasis on active exercises, hydrotherapy, rest-splints for affected joints, and salicylates. Steroid therapy has been given sparingly and (with the exception of twelve cases treated as part of the Medical Research Council trial of its value in early cases of rheumatoid arthritis) only to patients in whom the disease could not be controlled by simpler measures, when indicated by complications such as iritis, or (in some instances) when it had been given before admission and could not be discontinued. Thus, the majority of patients receiving steroids were those more severely affected by the disease. For the purposes of this analysis the term "maintenance steroid therapy" is restricted to those patients receiving continuous steroid therapy for a minimum period of 3 months; this was so in 63 of the 216 cases, and of these, 43 have received continuous therapy for more than one year. A lateral $x$ ray of the spine has been performed on these patients annually whenever possible and when specifically indicated by complaint of pain or loss of height.

\section{Incidence of Fractures}

26 of the 216 patients sustained fractures; in four this occurred on two occasions and in two on three occasions, giving an overall incidence of 34 fracture episodes. A single episode of trauma was responsible for multiple fractures, e.g. femur and tibia in two cases, so that the femur was involved in nineteen patients, the tibia in six, the humerus, radius, and fibula each in two, and the ulna and metatarsus each in one (a total of 33 long bone fractures), whilst in the remaining seven cases the vertebral column was involved. Fractures of the spine have been counted as single fractures, although in five cases there was involvement of more than one vertebral body (Table I).

\section{TABLE I}

INCIDENCE OF FRACTURES IN 216 CASES OF STILL'S DISEASE TO JUNE 1, 1959

\begin{tabular}{ccc|c|c|c|c}
\hline Therapy & $\begin{array}{c}\text { Total } \\
\text { No. } \\
\text { of } \\
\text { Cases }\end{array}$ & $\begin{array}{c}\text { No. } \\
\text { with } \\
\text { Fractures }\end{array}$ & $\begin{array}{c}\text { No. of } \\
\text { Fracture } \\
\text { Episodes }\end{array}$ & $\begin{array}{c}\text { Verte- } \\
\text { brae }\end{array}$ & $\begin{array}{c}\text { Other } \\
\text { Bones }\end{array}$ \\
\hline $\begin{array}{c}\text { Routine .. } \\
\text { Maintenance } \\
\text { Steroid }\end{array}$ & $\ldots$ & 153 & 19 & 25 & $2 *$ & 23 \\
\hline
\end{tabular}

* One of these patients had had two months cortisone therapy elsewhere.

$\dagger$ This includes two patients who previously sustained fractures on routine therapy. 
Sex and Age at Onset.- Six (6.7 per cent.) of the ninety males and twenty ( 15.0 per cent.) of the 126 females in the series had fractures. When the cases were further subdivided according to the age at onset, it was found that a high proportion of fractures occurred in girls in whom the disease commenced before the age of 5 years; this difference does not reach statistical significance (Table II).

TABLE II

AGE AND SEX OF CASES STUDIED

\begin{tabular}{|c|c|c|c|c|}
\hline \multirow{2}{*}{$\begin{array}{c}\text { Age } \\
\text { at } \\
\text { Onset } \\
\text { (yrs) }\end{array}$} & \multicolumn{2}{|c|}{ Males } & \multicolumn{2}{|c|}{ Females } \\
\hline & $\begin{array}{l}\text { Total No. } \\
\text { of Cases }\end{array}$ & $\begin{array}{l}\text { No. with } \\
\text { Fractures }\end{array}$ & $\begin{array}{c}\text { Total No. } \\
\text { of Cases }\end{array}$ & $\begin{array}{l}\text { No. with } \\
\text { Fractures }\end{array}$ \\
\hline $\begin{array}{l}0-5 \\
5-10 \\
10\end{array}$ & $\begin{array}{l}20 \\
33 \\
37\end{array}$ & $\begin{array}{l}1 \\
3 \\
2\end{array}$ & $\begin{array}{l}50 \\
31 \\
45\end{array}$ & $\begin{array}{r}14 \\
4 \\
2\end{array}$ \\
\hline Total & 90 & 6 & 126 & 20 \\
\hline
\end{tabular}

Severity of Disease.-All patients were graded according to the severity of the disease process as a whole, and classed as mild, moderate, or severe, and in patients who sustained fractures the presence of disease activity at the time of fracture was noted (Table III). Nineteen of the 26 patients were found to be in the most severely affected group, and in all of these the disease was active at the time of the fracture. The four inactive cases were all leading normal lives at the time of the fracture. In three the fracture was thought to be incidental-for example, a boy who fractured the tibial spire of an unaffected knee while playing rugby football, a girl who fell and sustained a Colles fracture in a wrist which was clinically and radiologically normal, and a girl whose fractured metatarsus was discovered on a routine foot $x$ ray. The fourth, however, had recovered from a mono-articular arthritis of the knee with a residual slight flexion deformity when she tripped and fell to the ground fracturing the femur immediately above the affected knee.

TABLE III

FRACTURES RELATED TO SEVERITY OF DISEASE

\begin{tabular}{|c|c|c|c|c|c|}
\hline \multirow{2}{*}{\multicolumn{2}{|c|}{$\begin{array}{c}\text { Severity of } \\
\text { Disease } \\
\text { Process }\end{array}$}} & \multirow{3}{*}{$\begin{array}{c}\begin{array}{c}\text { Total } \\
\text { No. of } \\
\text { Cases }\end{array} \\
32\end{array}$} & \multicolumn{3}{|c|}{ Cases Sustaining Fracture } \\
\hline & & & \multirow{2}{*}{$\frac{\text { Number }}{2}$} & \multirow{2}{*}{ Active } & \multirow{2}{*}{$\frac{\text { Inactive }}{2}$} \\
\hline Group I & Mild & & & & \\
\hline Group II & Moderate & 99 & 5 & 3 & 2 \\
\hline Group III & Severe & 85 & 19 & 19 & - \\
\hline
\end{tabular}

Immobilization.--Impaired movement due to pain and difficulty in using the affected joints is characteristic of rheumatoid arthritis, and when this is further limited by splints or rest in bed rapid osteoporosis results. More than half the patients in the series who subsequently sustained fractures had been $\vec{\theta}$ confined to bed elsewhere, usually with active arthriti for a period of at least 3 months during the course their illness. The period of rest was sometimes much longer when an initial diagnosis of rheumatie fever had been made (Case 1) or when systemic manifestations were marked.

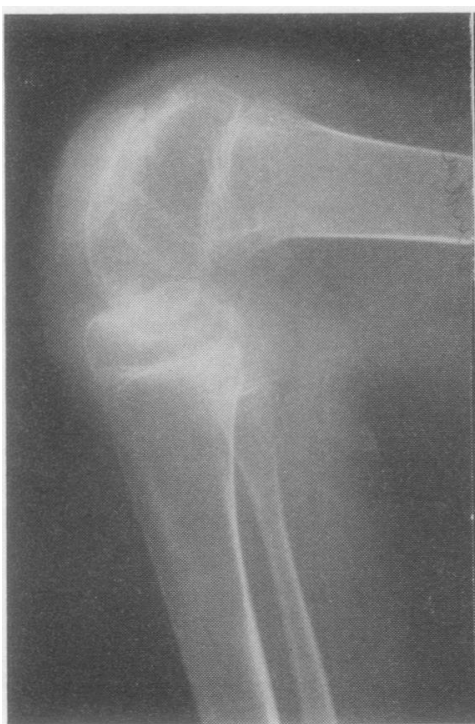

September, 1957

$1957 \quad$ November, 1957

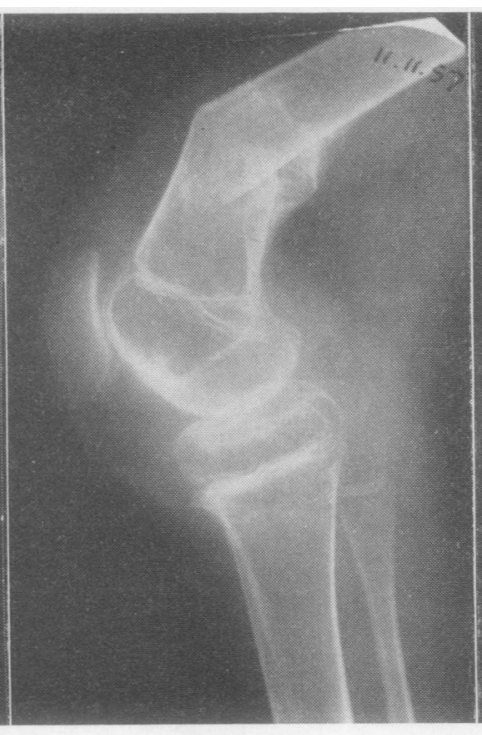

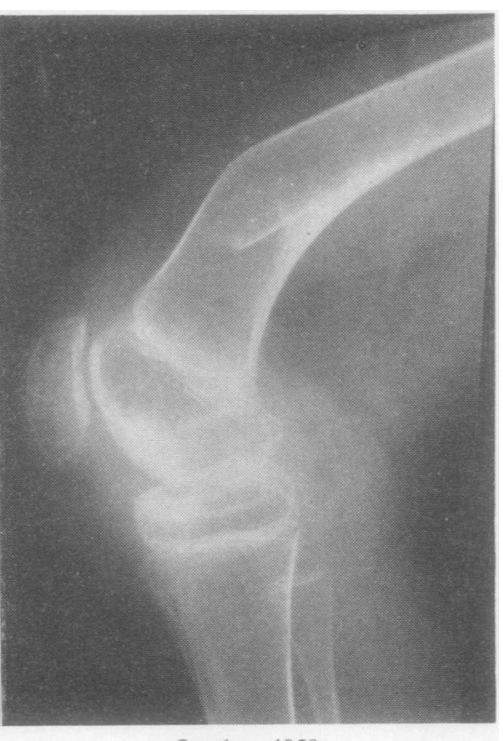

October, 1958

Fig. 1.-Fracture of femur following manipulation with subsequent healing but residual angulation (Case 1). 
Trauma.-Twenty fracture episodes followed an episode of trauma; this was of a minor character on fourteen occasions, for example a jolt in a taxi, but in seven cases the trauma occurred in children who had resumed normal activity and was more severe, varying from a skating accident and an injury at rugby football to being run over by a tractor. Three fractures were a direct result of manipulation (Fig. 1, opposite).

In eleven episodes no history of trauma was obtained; seven of these, including five vertebral fractures, occurred in the steroid-treated group.

Role of Maintenance Steroid Therapy.-Four fractures, two of which occurred within 7 days of starting steroid therapy, and another which resulted from a skating accident before the first 3 months of therapy had teen completed, as well as the fourth

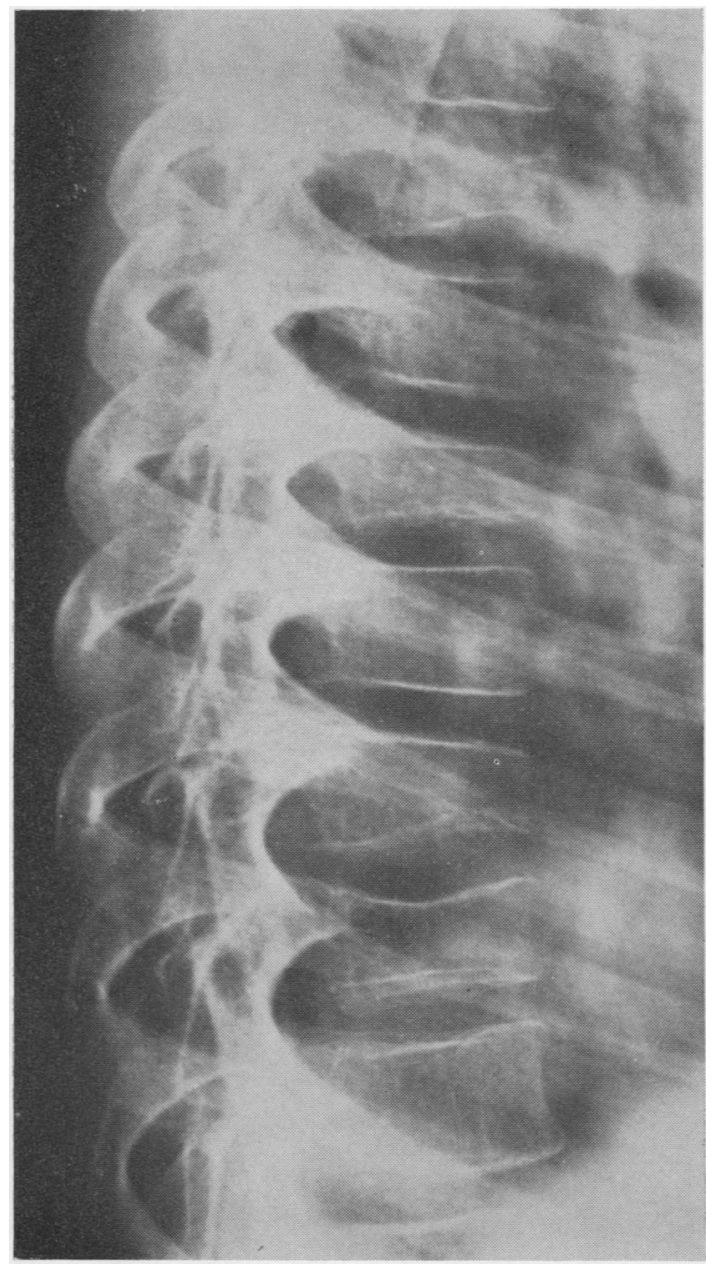

Fig. 2.-Multiple vertebral fractures in long-standing Still's disease on maintenance steroid therapy (Case 2). in a girl who had received 2 months' steroid therapy one year before admission, are included in the routine therapy group.

Nine patients on maintenance steroid therapy sustained fractures. Two patients, who had had fractures while on a conservative regime, later developed vertebral collapse while on maintenance steroid therapy, but preceding fracture cannot be used as a contraindication to such therapy as three similar cases have subsequently been maintained on steroid therapy without further incident. The type of therapy included ACTH, cortisone, prednisone, and triamcinolone, the daily maintenance dose varying between 25 and $100 \mathrm{mg}$. cortisone or its equivalent.

There was no obvious difference in the overall incidence of fractures in the two groups, but there was a significant difference in the site of fracture. Of the nine patients who sustained fractures whilst receiving maintenance steroid therapy, five showed $x$-ray changes of vertebral collapse (Fig. 2, Case 2), the duration of steroid therapy before the initial vertebral fracture being $7,13,20,21$, and 32 months respectively. Only two (Fig. 3) of nineteen patients in the other group showed similar changes and one of these had had 2 months of cortisone therapy one year previously.

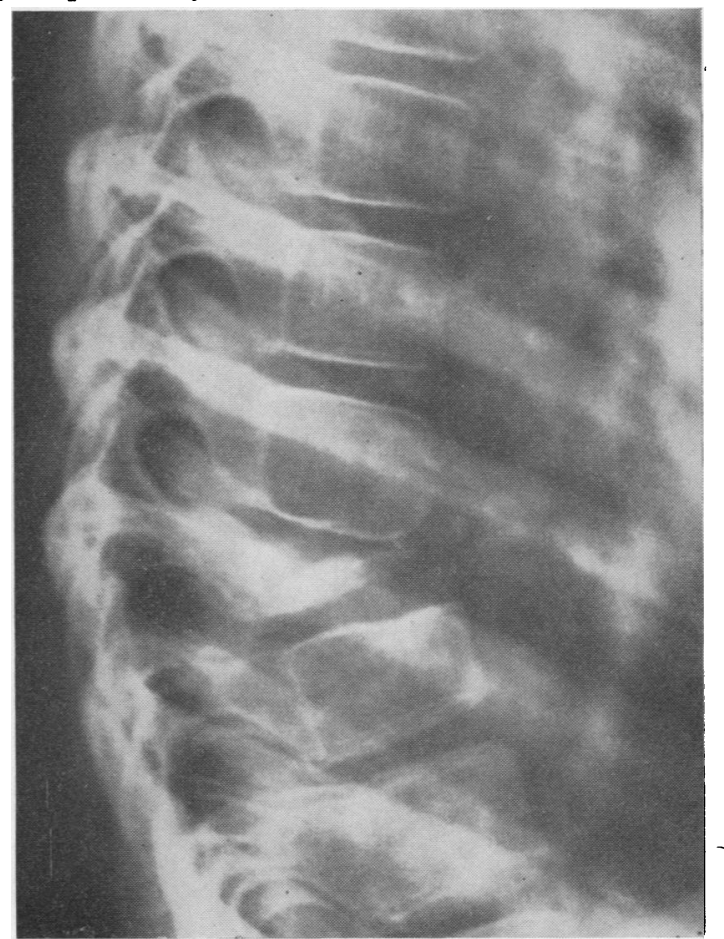

Fig. 3.-Collapse of 8 th dorsal vertebra (cf. Fig. 2) in a girl aged 7 who had had Still's disease for 4 years and had never received steroid therapy. 
TABLE IV

LESIONS OF THORACIC AND LUMBAR SPINE IN STILL'S DISEASE

\begin{tabular}{|c|c|c|c|c|c|c|c|c|c|}
\hline Therapy & $\cdots$ & $\cdots$ & $\cdots$ & $\cdots$ & $\cdots$ & \multicolumn{2}{|c|}{ Maintenance Steroid } & Routine & $\omega$ \\
\hline No. with Spinal $X$ Rays & $\ldots$ & . & $\cdots$ & . & $\cdots$ & $\begin{array}{l}\text { Less than } 1 \text { year } \\
1 \text { year or more }\end{array}$ & $\left.\begin{array}{ll}14 & (20) \\
41 & (43)\end{array}\right\} 63$ & $95(153)$ & $\ddot{\vec{C}}$ \\
\hline \multirow{4}{*}{ Lesions } & Vertebral & llapse & $\cdots$ & . & $\cdots$ & & 5 & $2 *$ & 을 \\
\hline & \multicolumn{5}{|c|}{ Adaptive Changes in Vertebrae } & & 1 & 4 & $\overline{\bar{\sigma}}$ \\
\hline & \multicolumn{3}{|c|}{$\begin{array}{l}\text { Other Vertebral Lesions } \\
\text { ? Osteochondritis }\end{array}$} & $\cdots$ & $\cdots$ & & 0 & 2 & 으 \\
\hline & \multicolumn{2}{|c|}{ Total } & . & . & . & & 6 & 8 & () \\
\hline
\end{tabular}

* This includes the patient who had cortisone therapy for 2 months before admission.

When the incidence of vertebral lesions in the whole series was reviewed (Table IV), slight narrowing of the anterior border of one or more vertebrae without true collapse was seen in some bed-fast cases, and this was thought to be adaptive.

\section{Method of Presentation}

Pain was the presenting symptom in all but one of the 25 fracture episodes which occurred in patients not having steroids, but in only five of those who were receiving steroids. The majority of vertebral fractures were discovered in the course of routine spinal $x$ rays, although occasionally they were suspected because of pain or apparent loss of height ${ }^{-}$ In only one (Case 2, Fig. 2) was there complaint of severe pain; this occurred with her first crush fracture and in subsequent incidents pain was not a pros nounced feature.

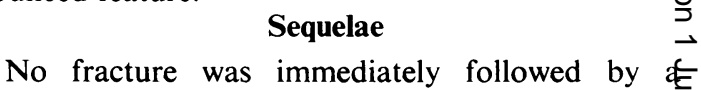
generalized flare of activity of the disease, but some local sequelae were noted, such as a recurrent knee effusion following a fractured femur in one giglo tubular resorption of the femur in a boy (Fig. $g$ )
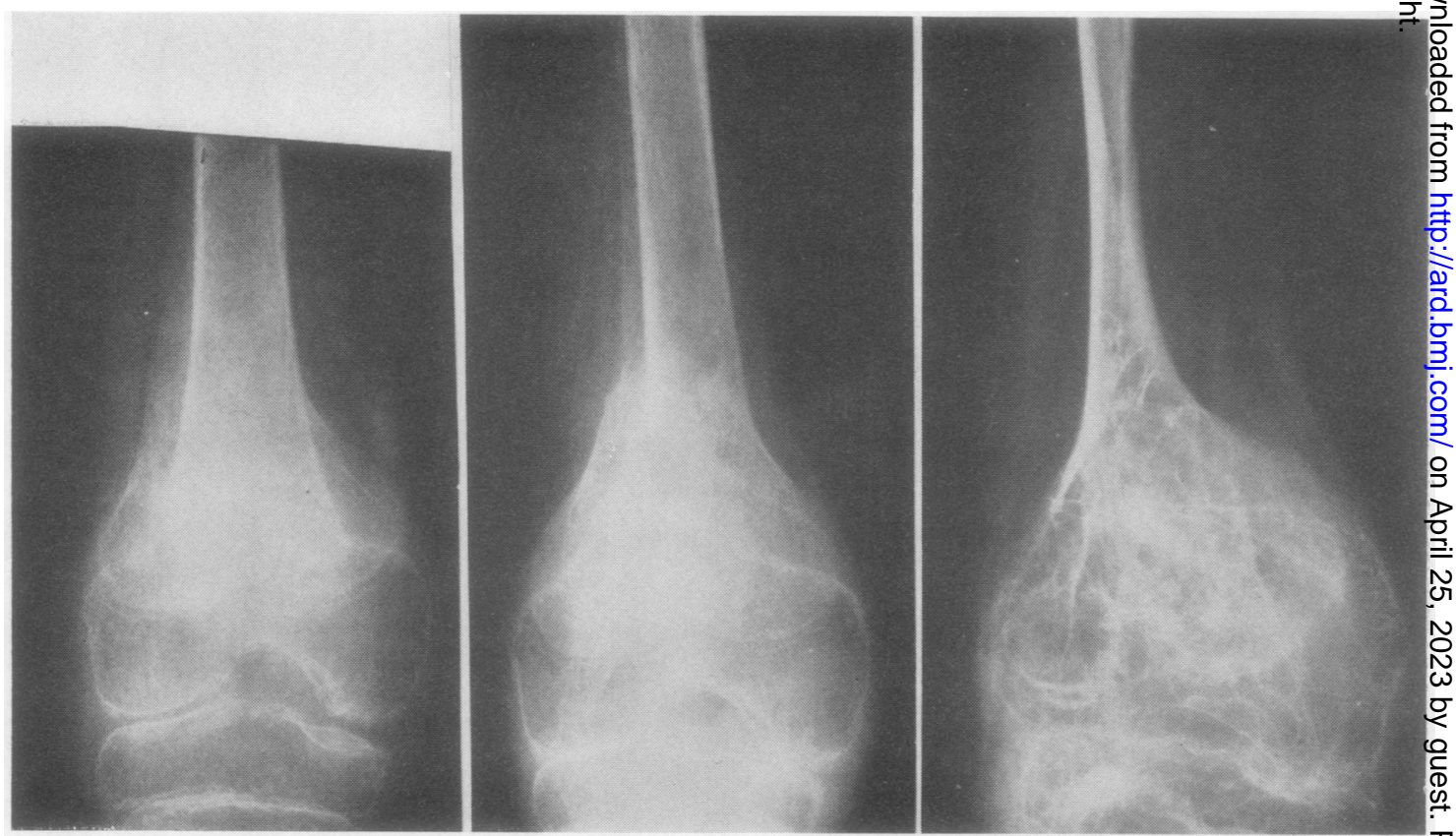

Fig. 4.-Development of tubular resorption of femur, which occurred over 4 years in a boy whose femur had been fractured during manipulation one year after the onset of severe Still's disease at age 9. 
There was also persistent angulation and flexion deformity of the femur in two cases (e.g. Case 1, Fig. 1), and ankylosis of an elbow following immobilization (Case 3, Fig. 5).

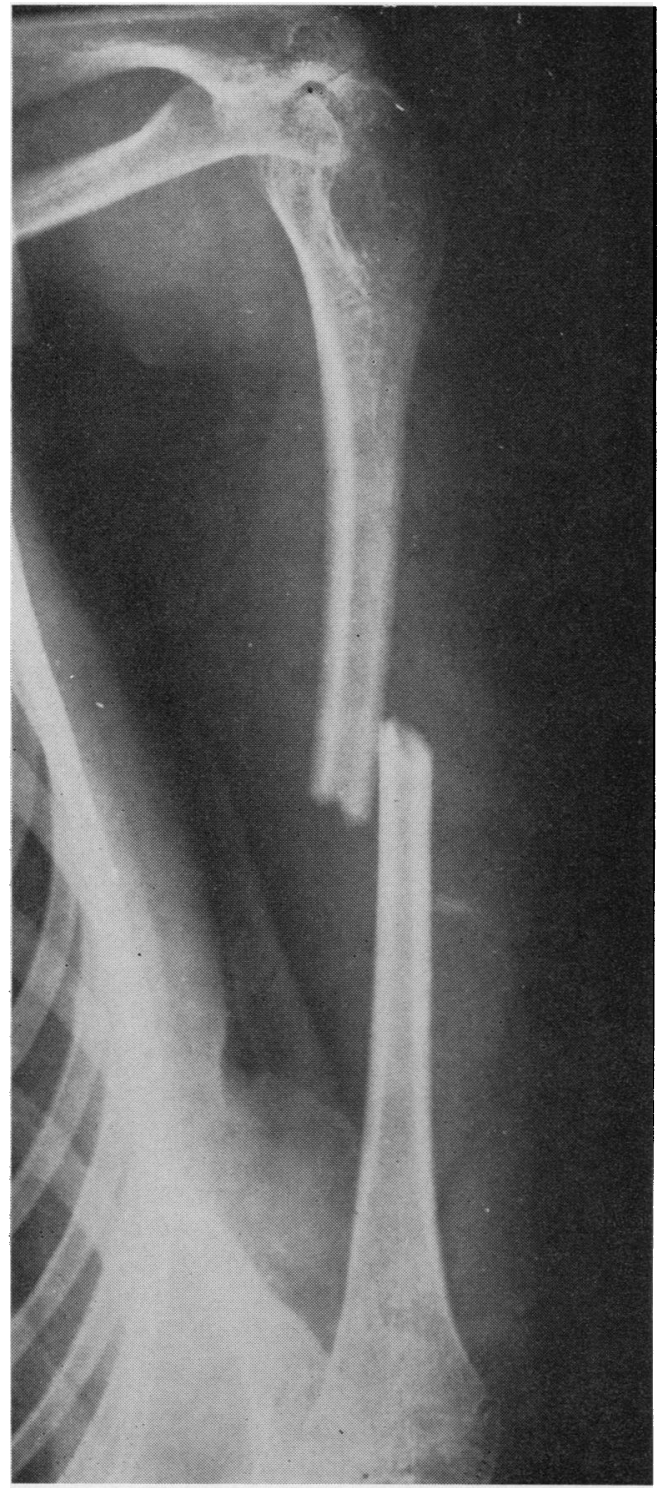

Fig. 5.-Fracture in mid-shaft of humerus after a fall at school, where the severely involved shoulder and elbow became fixed following immobilization (Case 3).

Both prolonged rheumatoid activity and the use of corticosteroids are associated in children with a failure to grow in height (Ansell and Bywaters, 1956), and the additional factor of vertebral collapse may exaggerate this deformity (Case 2, Fig. 2).
Healing of the long bones was not significantly retarded either by the presence of active disease or by steroid therapy in the dosage employed (Case 4 , Fig. 6).

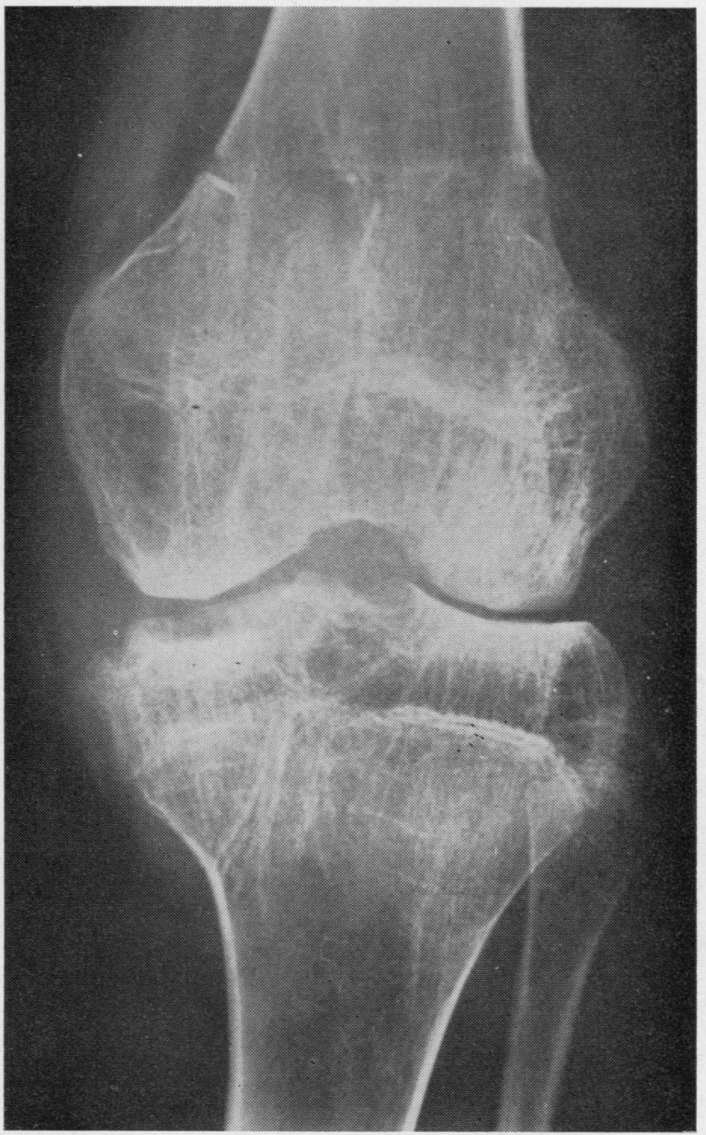

Fig. 6.-Healing of fractured femur which was treated with minimal immobilization, maintenance cortisone therapy being continued (Case 4).

\section{Discussion}

With the exception of the review of 157 cases of adult rheumatoid arthritis in which fractures occurred in 9.6 per cent. (Den Oudsten and Speyer, 1959), the number of children sustaining fractures in the present series (11.6 per cent.) appears higher than the figures given in previously published results in cases of adult rheumatoid arthritis. Indeed, Good, Vernier, and Smith (1957), when discussing the complications of steroid therapy, commented on the absence of fractures among 75 patients with Still's disease who had not received steroid therapy, while the large group of patients with both rheumatoid arthritis and degenerative joint disease 
described by Baer (1941) and the adults with rheumatoid arthritis receiving cortisone therapy reviewed by Boland (1951) have incidences of $1 \cdot 2$ per cent. and 2.6 per cent. respectively.

The high incidence of vertebral fractures in the steroid group in our small series is in agreement with other reports (Table V); of the fourteen patients with rheumatoid arthritis who sustained fractures described by Baer (1941) none of whom had received steroids, only one episode involved the vertebral column, whereas in the steroid-treated cases described by Boland (1951), Demartini, Grokoest, and Ragan (1952), and Curtiss, Clark, and Herndon (1954) vertebral fractures were more common, and Good and others (1957) comment on the occurrence of vertebral fractures in two patients with Still's disease who had received steroids.

When Cushing (1932) originally described the syndrome resulting from hypersecretion of the adrenal cortex, he commented on the marked osteoporosis of the skeleton and particularly of the spine. This observation has been confirmed in subsequent reports, such as that of Howland, Pugh, and Sprague (1958) who showed that of 69 patients whose radiological changes were reviewed, 68 showed osteoporosis affecting mainly the spine, pelvis, and ribs, with vertebral fractures in $\mathbf{4 2}$ per cent. usually involving the lower thoracic or upper lumbar spine. From the pathological viewpoint, Follis (1951) found rarefaction of the trabeculae with adequate numbers of osteoblasts and no evidence of osteoclastic resorption in the ribs and vertebra of four adults who had died from this disorder. Similar effects on retardation of chondrogenesis and osteogenesis have been reported after the use of ACTH in experimental animals (Baker and Ingle, 1948), and 꾹 negative calcium balances are well recorded in association with corticosteroid therapy (Sprague, Power, Mason, Albert, Mathieson, Hench, Kendall, $\frac{0}{\omega}$. Slocum, and Polley, 1950).

The high overall incidence of fractures in this $\overrightarrow{\bar{S}}$ series has led to a review of the management of our $\overrightarrow{0}$ cases. As both active disease and immobilization $\frac{C}{0}$ lead to osteoporosis (Ropes, Rossmeisl, and Bauer, $\overline{\bar{c}}$ 1943; Deitrick, Whedon, and Shorr, 1958), par- $ه$ ticularly in those children with disease commencing before the age of 5 years, immobilization, either क general or local, should be employed for the shortest $\overrightarrow{0}$ possible period. Rest in bed in the very acute stage $\vec{\overrightarrow{ }}$ and when indicated by severe or painful hip disease $\stackrel{\sim}{\sigma}$ should be accompanied by daily active exercises, assisted if necessary at the outset, and adequate analgesics should be given to allow this active $\overrightarrow{0}$ participation, while hydrotherapy should be em- ? ployed whenever it is available. Even when weight- $\vec{\omega}$ bearing is allowed, the necessity for active exercises under supervision is still present. Once improvement is well under way, the patient should be $\vec{c}$ encouraged to lead as normal a life as possible, but full physical activity should not be advised until the disease is completely quiescent, as minor injury can $\overrightarrow{\mathscr{Q}}$ cause a fracture while osteoporosis persists. Th 8 need for continued daily exercises at home during this period is stressed at each out-patient visit.

The use of rest-splints from the onset will prevent the majority of deformities, but if these do occur manipulation of a joint should not be undertaken until adequate serial splinting has failed to improve its position.

The indications for corticosteroid therapy should

TABLE V

FRACTURES IN ARTHRITIS

\begin{tabular}{|c|c|c|c|c|c|c|c|}
\hline \multirow[b]{2}{*}{ Date } & \multirow[b]{2}{*}{ Author } & \multirow{2}{*}{$\begin{array}{l}\text { No. of } \\
\text { Cases }\end{array}$} & \multirow{2}{*}{$\begin{array}{l}\text { Type of } \\
\text { Disease }\end{array}$} & \multirow{2}{*}{$\begin{array}{l}\text { Steroid } \\
\text { Therapy }\end{array}$} & \multicolumn{3}{|c|}{ Patients Sustaining Fractures } \\
\hline & & & & & Number & Vertebrae & $\begin{array}{l}\text { Other } \\
\text { Bones }\end{array}$ \\
\hline 1941 & Baer & 1,625 & $\begin{array}{l}\text { Chronic Arthritis (Degenerative } \\
\text { Joint Disease }+ \text { Rheumatoid } \\
\text { Arthritis) }\end{array}$ & - & $\begin{array}{l}21 \\
\text { (14 with } \\
\text { Rheumatoid } \\
\text { Arthritis) }\end{array}$ & 1 & 13 \\
\hline 1957 & Good and others & 75 & Juvenile Rheumatoid Arthritis & - & - & 一 & - \\
\hline 1959 & Den Oudsten and Speyer & $\begin{array}{r}143 \\
14\end{array}$ & $\begin{array}{l}\text { Rheumatoid Arthritis } \\
\text { Rheumatoid Arthritis }\end{array}$ & $\overline{+}$ & (9.6 per cent.) & 4 & 11 \\
\hline 1951 & Boland & 76 & Rheumatoid Arthritis & + & 2 & 1 & 1 \\
\hline 1952 & Demartini and others & $?$ & Rheumatoid Arthritis & + & 5 & 5 & 1 \\
\hline 1954 & Curtiss and others & $?$ & $\begin{array}{l}\text { Rheumatoid Arthritis } \\
\text { (1 juvenile) }\end{array}$ & + & 4 & 4 & - \\
\hline 1955 & Bunim, Ziff, and McEwen & 8 & Juvenile Rheumatoid Arthritis & + & - & - & - \\
\hline 1957 & Good and Others & $?$ & Juvenile Rheumatoid Arthritis & + & 2 & 1 & 1 \\
\hline
\end{tabular}


be carefully weighed against the very real risk of multiple vertebral fractures, which are particularly likely to occur when osteoporosis is already present. Thus, preliminary assessment of each case includes a lateral $x$ ray of the thoracic and lumbar spine. As steroid therapy is frequently associated with marked weight increase, some restriction of diet is often required and when this is ordered in children it is wise to bear in mind that the intake of bread and milk, both good sources of calcium, is frequently reduced, so that if this restriction continues for any length of time calcium supplements are desirable. The value of anabolic steroid in preventing calcium loss due to corticosteroid is not known. Short-term studies have shown that calcium retention can be induced with the concurrent use of Nilevar in moderately high dosage (Stokes, Horwith, Pennington, and Clarkson, 1959), but whether it is possible to cover maintenance steroid therapy without running into side-effects from the anabolic steroid is still not certain.

Despite all these measures, fractures do occur, and when this happens they require special management with the shortest possible period of immobilization, together with intensive physiotherapy and rapid rehabilitation (Case 4, Fig. 6).

\section{Summary}

(1) In a series of 216 cases of juvenile rheumatoid arthritis, 26 patients sustained fractures, six on more than one occasion; five of the seven spinal fractures involved multiple vertebrae.

(2) There appeared to be a higher incidence of fractures in female patients in whom the disease commenced before the age of 5 years.

(3) 63 patients received maintenance steroid therapy and although the total incidence of fractures was not significantly different in those given steroids from that in those not given steroids, the incidence of vertebral collapse among those on steroid therapy was significantly higher.

\section{REFERENCES}

Ansell, B. M., and Bywaters, E. G. L. (1956). Ann. rheum. Dis., $15,295$.

Baer, G. J. (1941). Ibid., 2, 269.

Baker, B. L., and Ingle, D. J. (1948). Endocrinology, 43, 422.
Boland, E. W. (1951). Brit. med. J., 2, 191.

Bunim, J. J., Ziff, M., and McEwen, C. (1955). Amer. J. Med., $18,27$.

Curtiss, P. H., Clark, W. S., and Herndon, C. H. (1954). J. Amer. med. Ass., 156, 467.

Cushing, H. (1932). Bull. Johns Hopk. Hosp., 50, 137

Deitrick, J. E., Whedon, G. D., and Shorr, E. (1948). Amer. J. Med., $4,3$.

Demartini, F., Grokoest, A. W., and Ragan, C. (1952). J. Amer. med. Ass., 149, 750 .

Den Oudsten, S. A., and Speyer, B. (1959). Ned. T. Geneesk, $103,15$.

Follis, R. H., Jr. (1951). Bull. Johns Hopk. Hosp., 88, 440.

Good, R. A., Vernier, R. L., and Smith, R. T. (1957). Pediatrics, 19, 95 .

Howland, W. J., Jr., Pugh, D. G., and Sprague, R. G. (1958). Radiology, 71, 69.

Ropes, M. W., Rossmeisl, E. C., and Bauer, W. (1943). J. clin. Invest., 22,785 .

Sprague, R. G., Power, M. H., Mason, H. L., Albert, A., Mathieson D. R., Hench, P. S., Kendall, E. C., Slocumb, C. H., and Polley, H. F. (1950). Arch. intern. Med., 85, 199.

Stokes, P. E., Horwith, M., Pennington, T. G., and Clarkson, B. (1959).' Metabolism, 8, 709.

\section{Fractures dans la maladie de Still}

\section{RÉSUMÉ}

(1) Dans une série de 216 cas d'arthrite rhumatismale juvénile, 26 cas subirent diverses fractures, six d'entre eux plus d'une fois. Dans cinq cas sur sept de fracture de la colonne vertébrale, plusieurs vertèbres furent atteintes.

(2) La proportion des fractures semblait être plus grande chez des filles dont la maladie avait commencé avant l'âge de cinq ans.

(3) Dans cette série, 63 cas furent soumis à une thérapie de maintien par des stéroïdes et, bien que le nombre total de fractures chez ceux-ci ne fût pas appréciablement différent par rapport aux autres, la fréquence de l'affaissement vertébral chez eux fut appréciablement plus grande.

\section{Fracturas en la enfermedad de Still}

\section{Sumario}

(1) Entre una serie de 216 casos de artritis reumatoide juvenil, 26 sufrieron fracturas diversas, seis de ellos en más de una ocasión. En cinco de las siete fracturas de columna vertebral encontradas, habían sido afectadas varias vértebras.

(2) La mayor incidencia de fracturas aparece entre enfermas cuyo padecimiento comenzó antes de los cinco años de edad.

(3) Sesenta y tres casos de esta serie estuvieron sometidos a una terapéutica de mantenimiento con esteroides $y$, aunque no se encontró ninguna diferencia significativa en cuanto al número total de fracturas en éstos en relación con los demás, la incidencia del aplastamiento vertebral fué significativamente mayor dentro del grupo que recibió tratamiento con esteroides.

\section{APPENDIX}

\section{Case Reports}

Case 1. A girl when aged 6 commenced with polyarthritis and constitutional symptoms in April, 1956, and was admitted to this hospital in August, 1957, with severe involvement and deformity of elbows, wrists, hands, hips, knees, and ankles. As only limited progress was made on salicylate and physiotherapy, her hips and knees were manipulated and she was started on steroid therapy. 
Routine $x$ rays taken after manipulation confirmed a supracondylar fracture of one femur with angulation; this was treated with splinting and gradual remobilization (Fig. 1).

Prednisone $(10 \mathrm{mg}$./day) caused a steady improvement in her clinical state but attempts to reduce the dosage caused marked deterioration, so she continued at this dose. After 21 months she was noted to have lost half an inch in height, and an $x$ ray revealed collapse of the 7 th dorsal vertebra.

Case 2. A girl aged 14 months in 1948 developed arthralgia, fever, rash, nodules, and lymphadenopathy which lasted for 6 months. She then remained well until the age of 4 years when she was re-admitted to hospital complaining of abdominal pain. Laparotomy was unhelpful, her pyrexia persisted, and she subsequently developed pericarditis and arthritis. Steroid therapy for 2 months caused a marked improvement which was maintained until the relapse for which she was admitted to this hospital in February, 1952.

She was then found to have polyarthritis, a typical rash, lymphadenopathy, hepatosplenomegaly, fever, anaemia, and generalized osteoporosis. Shortly after admission she was given suppressive cortisone therapy (100-62.5 mg./day for one year, then $37.5 \mathrm{mg}$./day). She was discharged after 19 months in hospital and followed as an out-patient when repeated attempts were made to reduce her steroid dosage.

After 32 months of continuous therapy she was re-admitted in November, 1954, complaining of pain in the back, and an $x$ ray of the dorsal spine showed a compression fracture of D.8. Steroid dosage was lowered, although her clinical condition deteriorated, and was finally stopped in March, 1955, after a haematemesis requiring blood transfusion. An attack of measles in June, 1955, was followed by remission, and she was discharged, but during the next year her condition steadily deteriorated until in July, 1956, she was bed-fast with widespread active arthritis and was almost moribund. After many painful interviews with the mother, steroid therapy was reluctantly restarted and during the next 2 years, whilst on hydrocortisone and later triamcinolone, further fractures, the majority painless, were found in seven other dorsal and lumbar vertebrae (Fig. 2). In addition she has developed pseudoxanthoma elasticum, and a clinical diagnosis of amyloidosis was confirmed in 1958.
Case 3. A girl aged $2 \frac{1}{2}$ years developed pain and $\underset{7}{7}$ swelling of the small joints of the hands and feet, followed by pain in the hips, knees, and elbows. A diagnosis of $\overline{3}$ rheumatic fever was made elsewhere and she was kept $\square$ in bed for 6 months by which time the joints had fully recovered. When she was aged 5 , joint pains recurred and she was again treated as a case of rheumatic fever for a further 6 months at the same hospital.

For the next 2 years she remained generally unwell $\frac{\square}{\sigma}$ and when re-admitted at the age of 7 years a diagnosis of Still's disease was made and she was treated with gold $\overparen{\Phi}$ injections and immobilization.

From that time until admitted here at the age of 110 she was unable to walk. After 8 months of intensive $\overrightarrow{0}$ physiotherapy she was mobilized on walking sticks and able to get about freely. One year later while at school $\vec{\omega}$ she fell and fractured the mid-shaft of the humerus (Fig. 5). This was treated locally by immobilization in plaster, but after removal of the plaster both the elbow? and shoulder were fixed and she has subsequently required $\overrightarrow{0}$ an arthroplasty of the elbow.

Case 4. A girl aged 8 was admitted to hospital in 1952 ज with fever, polyarthritis, and pericarditis. During the next 3 years, three further relapses were treated with cortisone.

When she was admitted to this hospital at the age of $11 \frac{\bar{D}}{\mathrm{D}}$ years there was widespread joint involvement which $\rightarrow$ improved on salicylates and intensive physiotherapy. A subtrochanteric abduction osteotomy was performe in 1956 for adduction deformity of the left hip. Physie therapy was continued whilst she was in bed and seres recommenced walking with support 2 months later. $\stackrel{\supset}{\rightleftharpoons}$

6 months after the operation a further acute exacerbation was treated with steroids and she has since been $\frac{\circ}{\Phi}$ on maintenance therapy (cortisone $50 \mathrm{mg}$./day). She $\varrho$ remained well and mobile until in 1959 at the age of $\overrightarrow{\overrightarrow{0}}$ 15 years, she fell downstairs and sustained a transverse $\frac{0}{3}$ fracture of the left femur 2 inches above the knee. She was admitted to our orthopaedic unit and the leg was put in a Thomas's splint for 4 weeks. During this period she continued on maintenance steroids and had daily physiotherapy. She was then mobilized in the $\frac{\sigma}{\sigma}$ hydrotherapy pool for 4 weeks. After a further 4 weeks 3 she was able to walk without a caliper and 3 weeks later she was discharged. At that time the affected hip and $\frac{0}{3}$ knee on the fractured side showed exactly the same mobility as before the fracture (Fig. 6). 